might be more appropriately shown in a special collections area than the lobby of an undergraduate library.

Most library exhibit programs would benefit from broader participation by library faculty and staff in their planning and execution. Although special skills are involved in exhibit preparation, an experienced installer or a committee appointed to oversee exhibitions could assist with technical questions. Library exhibits offer a fine opportunity to bring patrons and information together under enjoyable circumstances.

While exhibitions are a secondary function of academic libraries, they may make a substantial contribution to the academic community. An exhibit catalog published in-house can correlate and present information which is otherwise unavailable. This is especially true for collections of local and regional materials. Because libraries generally approach exhibitions from a contextual perspective, skillfully written captions and commentaries may encourage viewers to relate materials in new ways. Occasionally campus libraries may provide alternative exhibition space for shows deemed inappropriate for the art gallery or museum. And on occasion library exhibit planners should take their shows "on the road" to the student union or administration building. The services offered by academic libraries and the astonishing variety of materials they house deserve wider recognition.

The conception of an exhibit idea, the research needed to choose items to be included and the organization of these materials into a meaningful presentation are a challenge for the exhibit planner. At its best, the academic library exhibit is a scholarly effort subject to review by a large audience. Although few libraries can mount exhibits on the scale of the New York Public Library's recent show, "Censorship: 500 Years of Conflict," such efforts should serve to inspire the library community to use exhibitions more purposefully.

\title{
ACRL and higher education
}

\author{
By JoAn S. Segal and Sharon Rogers
}

\section{The ACRL executive director and president visit the}

\section{higher education community in Washington, D.C.}

$\mathrm{S}_{\text {i }}$ Washington, D.C., where many higher education associations have their headquarters, Sharon Rogers and JoAn Segal decided the visit might afford an opportunity to meet with leaders in those associations to establish some links between the professional association for academic librarians and the associations dealing with the academy in its other aspects. On January 11 we visited the American Association for Higher Education (AAHE), the Association of American Colleges (AAC), the Chronicle of Higher Education, and the American Council on Education (ACE).

At AAHE, we had an excellent visit. The Association, like ACRL, is one of individual members. Most of the members are administrators in institutions of higher education. An important activity of this association is the National Conference on Higher Education (NCHE), which will be held this year in Chicago. AAHE seeks a broad base of membership, and offers through its National Conference the opportunity for networks of educators to meet together and to establish relationships within their own groups and between the groups. We 
were invited to use the National Conference as a way of improving our networking activities with others in the field of higher education.

It is possible, for example, for us to meet on an informal level, to hold committee meetings at the time and place of the conference, to exhibit, to hold a reception, or to design some kind of joint session. We decided that participation in this year's Conference was very important for us, since the Chicago location makes it possible for us to study the meeting with an eye to how we can use it most effectively to advance the linking of librarians and other academics. As a result, we have taken an exhibit booth for Choice magazine, and both Rogers and Segal will attend the meetings, participating actively with a group of academic librarians including Beverly Lynch, Joanne Euster, Patricia Breivik, and other ACRL members, who will actively seek ways to bring the library role and presence to bear in this important national association.

Lunch with Mark Curtis of the Association of American Colleges was an equally positive experience. Curtis suggested that ACRL might be interested in an affiliate membership in AAC. In addition, he stressed that since the members of the Association are colleges there might be a good possibility for some joint grant activity dealing with libraries and their impact in four year institutions. The annual meeting of the AAC took place in Washington, February 10-13, and at that time the Association released an important report, Integrity in the Curriculum, which voiced concern about undergraduate education, the faculty role, and the need to provide an integrating experience for the undergraduate. We plan to write a reaction paper, but have not yet done so. We will follow up on the affiliate membership idea and keep joint activity in mind.

At the Chronicle of Higher Education we had the opportunity to meet with three women whose knowledge of the field of higher education and of the role of academic libraries was notable. We shared information with them about what is happening in the library world, and our conversation ranged from scholarly publications and interlibrary loan to the issues of access, legislation, and library automation. The discussion was lively and we hope will have the effect of giving the Chronicle a source of information regarding academic librarianship upon which they will call in the future. In fact, during the Conference there was considerable coverage by the Chronicle and we were asked to assist in the preparation of an article involving an interview with an academic librarian. (The interview with Carolyn Dusenbury appeared in the February 27 issue.)

At the American Council on Education we met with the new Research Director, Janice Petrovich, who discussed with us the opportunities for participation with ACE in its ongoing activities. The Council is an association of institutional members. In fact, the American Library Association is a member of ACE. It holds regular workshops and meetings throughout the country. We discussed the possibility of working jointly with ACE in developing workshops, and in using resources of ACE to enrich the learning experiences of academic librarians. We also identified two groups meeting in the Washington, D.C., area in the field of higher education research and have decided to make some overtures to those groups as well.

Subsequent to our meeting with Petrovich we were asked to prepare a proposal for ACRL participation in the ACE Annual Meeting in Florida in October. The theme of the meeting is Corporate/Campus Cooperation. We have suggested a panel on the academic library, its potential role in providing information services to corporations, and its need for the financial support of those same corporations.

We will continue to follow up on the contacts made in Washington and will continue, under the coordination of the Professional Association Liai-

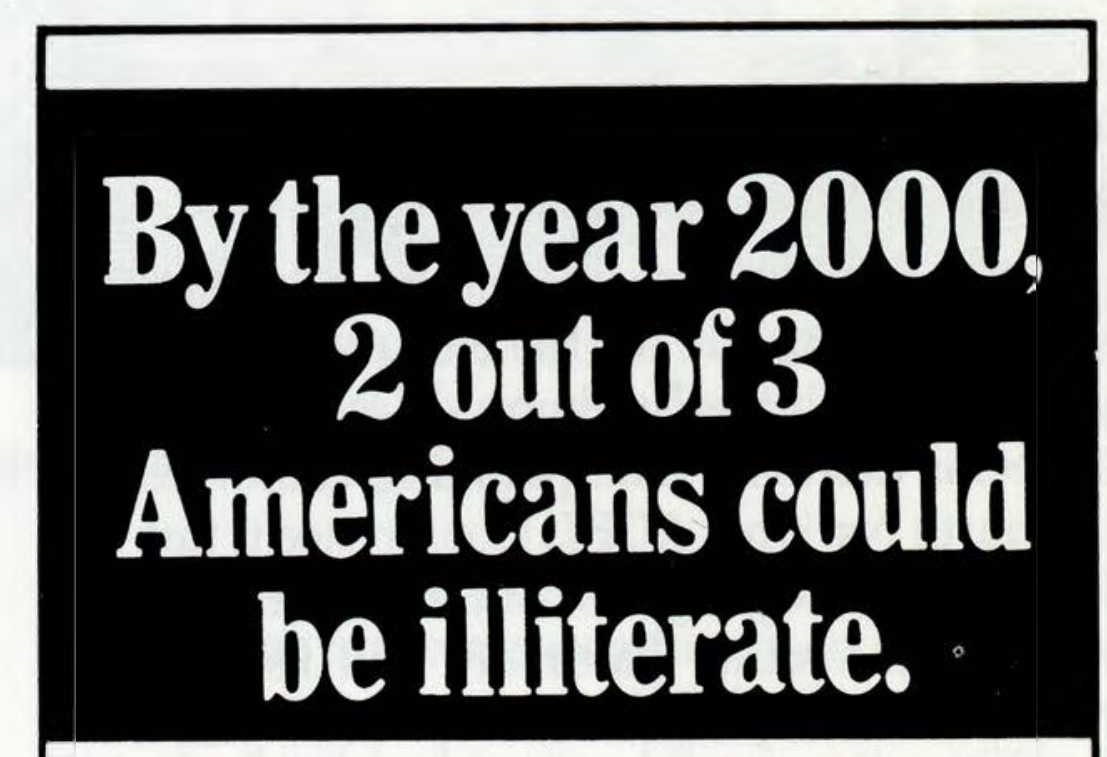

It's true.

Today, 75 million adults.. about one American in three, can't read adequately. And by the year 2000, U.S. News \& World Report envisions an America with a literacy rate of only $30 \%$.

Before that America comes to be, you can stop it.. by joining the fight against illiteracy today.

Call the Coalition for Literacy at toll-free 1-800-228-8813 and volunteer.

\section{Volunteer Against Illiteracy. The only degree you need is a degree of caring.}

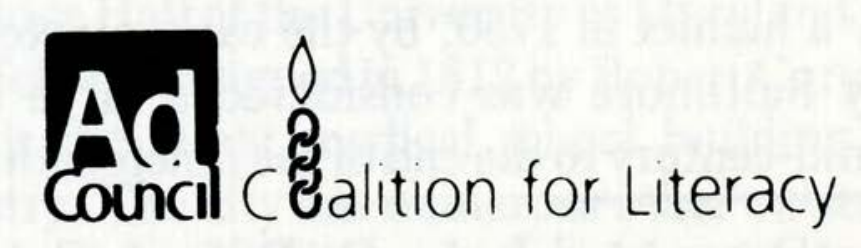


son Committee chaired by Joan Chambers, to make contacts with other higher education associa- tions and to work cooperatively in bringing librarians into the mainstream of academia.

\section{Baltimore '86}

\section{Baltimore epitomizes "Energies for Transition."}

\section{$\mathbf{P}$} resent day Baltimore is changing dramatically in its race to prepare for the electronic, high-tech future to which the Baltimore-Washington corridor seems destined. The planning committee for the Fourth National ACRL Conference is just putting together the program, but it is not too early to think about visiting Baltimore and its environs. Baltimore is a city of the future, but its past is still visible to the casual observer. The energy of Baltimoreans has fueled a succession of urban transformations over the city's long history. Hence, Baltimore epitomizes the theme chosen for the ACRL Conference, "Energies for Transition," which is to be held at the Convention Center April 9-12, 1986.

\section{History}

The City Leaders are fostering attempts to learn from the past and to preserve outstanding achievements of earlier times. Baltimoreans recognize the truth of what John Dos Passos said of this city in 1968:

"Some day the prime movers who decide our destinies may come to understand that the character of a city as a fit place for men and women to live depends on the survival of intriguing vestiges of the past."l

Witness four inner-city archaeological digs in recent months and the $\$ 11$ million late 1970 s restoration of the 1875 City Hall with its magnificent rotunda and dome.

Only a hamlet in 1750 , by the early nineteenth century Baltimore was considered a large city. From mid-century to the end of the nineteenth cen-

\footnotetext{
${ }^{1}$ John Dorsey and James D. Dilts, A Guide to Baltimore Architecture (2d ed., Centreville, Md.: Tidewater, 1981), p. xv.
}

tury, Baltimore doubled its population again. One can now easily spot from atop Federal Hill or the World Trade Center the geographical featuresthe Piedmont fall line to the West and the sheltered harbor on the East-which provided the energy and outlet for Baltimore's productivity. The city's maritime and industrial heritage is depicted well in the Baltimore Museum of Industry, one of the newest of our city's forty plus museums and galleries.

Called the northernmost Southern city in the country, Baltimore shared in the strengths of both regions. In the thriving nineteenth century, three of the four Baltimoreans who gave their names to world-renowned city institutions were Yankees. Enoch Pratt (of library fame), born in Massachusetts, augmented his already considerable fortune by controlling the horseshoe and mule-shoe business during the Civil War. By 1830 George Peabody, also from Massachusetts, was the senior partner of the largest mercantile house in the country. In 1857 he set about creating the Peabody Conservatory, long the center of Baltimore's musical life, and the Peabody Library, now under the control of Johns Hopkins University. Hopkins was the native Marylander of the four, while the other Yankee was William T. Walters, originally from Pennsylvania, whose collecting penchant eventually resulted in the Walters Art Gallery. The Peabody is one of the cornerstones of Mount Vernon Place, the square surrounding Robert Mill's monument to George Washington, finished in 1829. Mount Vernon and nearby beautiful squares were home to many prominent families, some of old Maryland stock. Baltimore looked to the South for guidance in the matters of cookery, hospitality, and the social conventions generally. Henry James once called these squares of Mount Vernon "the parlour 